\title{
Exhibition
}

\section{A window on the past}

Glassware used to be very precious but, as with all commodities, more efficient production methods made the price tumble. This is what happened in Roman times.

Inventories from houses in Pompeii show that by 79 AD when volcanic ash from Vesuvius smothered the city - the middle classes had replaced most of their metal household vessels with glass ones. Glass was still too expensive for poor households, but was apparently too cheap for the rich, who seemed to have stuck with their gold and silver vessels.

The exhibition "Vitrum", which runs until 31 October in Florence, shows how Roman technologists made glass affordable - in large part by perfecting glassblowing techniques, which vastly increased its versatility too. They also developed other techniques, such as glass 'cameoing', and colouring using different metal oxides.

With its new and seductive transparency, glass quickly won over many levels of society. In

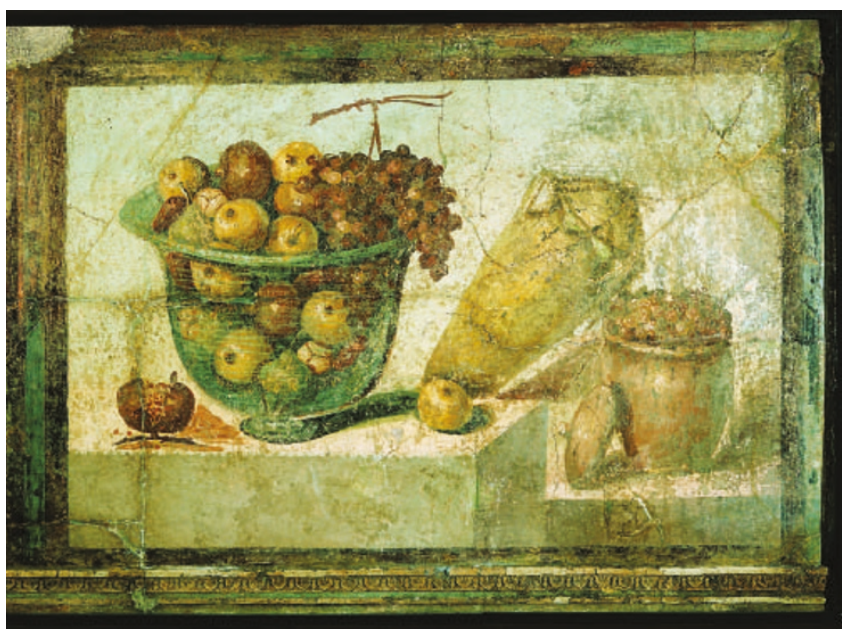

properties that further lightened domestic space.

The scientific élite also embraced glass for its own pragmatic and experimental purposes. Physicians began to use glass urine containers. Urine was a major diagnostic aid in those days, and a transparent vessel that allowed its colour to be easily monitored was a boon. Sealed glass ampoules also came into common use to protect pharmaceutical preparations from contamination.

In the second century AD, Ptolemy used variously shaped vessels - "made of glass that is

the Pompeii mosaic above, the fruit bowl, whose fruit is sparklingly visible within it, is clearly a source of domestic pride. But glass also transformed architecture. Many glass window panes have been found in Pompeii, replacing the traditional cloth hangings that left interiors dark. Mosaics for walls then became popular, using coloured glass chips which had reflective as thin and pure as possible so they are transparent" - that he filled with water, to demonstrate his laws of optical refraction.

This unusual and informative exhibition enjoys an exceptional location in Florence's fifteenth-century Palazzo Pitti, in rooms whose walls are completely frescoed.

Alison Abbott

\section{Exponent of the exponential}

\section{The Man Who Shocked the World: The Life and Legacy of Stanley Milgram \\ by Thomas Blass \\ Basic Books: 2004. 368 pp. \$26, £19.99}

\section{Steve Blinkhorn}

It's a sin to tell a lie - or is it? Experimental psychology has always engaged in modest amounts of subterfuge to distract human subjects from the true purpose of investigations. Experimental social psychology, or at least one branch of it, goes much further and makes deceit in social interaction the pith and essence of investigative practice. The usual social norms of sincerity, spontaneity and good faith are discarded to provoke attitudes or behaviour in unsuspecting human subjects: this is true experimental manipulation in the interests of a science of social behaviour.

Stanley Milgram was an outstanding exponent of this style of research, but to what end? His famous experiments on obedience, where subjects were duped into believing they were administering painful and even dangerous electric shocks to other volunteers in the course of a banal learning experiment, both launched and blighted his professional career. Like so much else of his work, they made manifest a sublime talent for dramatizing and presenting what was already known about the moral frailty of humankind. Who since Shakespeare, or even Sophocles, has believed that human behaviour is governed by the rational evaluation of alternatives under the guidance of a wellexamined conscience? Lawyers, perhaps. Milgram found ways of capturing this frailty without adding substantially to our understanding of it, or to our ability to remedy it.

The writer of this welcome but flawed biography, Thomas Blass, thinks otherwise. The author of more papers on Milgram than Milgram himself ever published, he veers from pointed critical evaluation of Milgram's work and character to overblown hagiographic praise. We are invited to think of Milgram as great, with an ever-present sense of muffled outrage at the failure of Harvard University to grant him tenure. The puffery extends to a dust-jacket endorsement by a professor of physics, who extols Milgram as the most influential social psychologist of the past century. When did physicists ever look to psychologists to evaluate the standing and contribution of their own peers?

A careful reading reveals that Milgram was a chippy colleague, often unpleasant to his students, and had two characteristics often taken as warning signs of unreliability: a drug habit and a sense of entitlement.

In fact, for all his undoubted talent for communication to a wider public, Milgram singularly failed to win research grants from major funding bodies, saw remarkably few students through to completion of doctoral studies, and turned increasingly to the media as an outlet for his talents. He lived his research methods. When he burst into a seminar with the news of John F. Kennedy's assassination, it was simply assumed that this was Milgram up to his usual tricks, trying another experimental social manipulation.

The other major contribution attributed to Milgram, beyond his obedience work and some technical methods for unobtrusive research, concerns the idea of six degrees of separation: that anyone can find a chain of acquaintance with anyone else on Earth that has about six links. This idea has ramifications not just in the study of social networks, but also in computing and mathematics. It is little elaborated in this work, perhaps because Milgram himself did little to elaborate it, beyond the bold statement published in the first issue of Psychology Today.

But how bold was it? To untutored common sense it may seem surprising, but untutored common sense falls prey to chain letters and pyramid selling schemes, which share essentially the same mathematics, and has little grasp of the reach of exponential arithmetic. To make six degrees of separation a fair representation of reality, on a hopelessly simple model (and the interesting issues are all to do with why such a simple model is inadequate) at the time Milgram was writing, the average number of unique 


\section{books and arts}

acquaintance links per person was 42 . This perhaps casts the Meaning of Life, the Universe and Everything in a new light. Our talent for procreation, however, has subsequently increased the number to 43 .

This is an uneven book - perhaps an overzealous editorial hand has been at work. You will feel at home reading it if you know the detailed topography of Harvard University, what a summer salary is and why it is important, the precise nature of a proseminar, the US system of academic appointment and tenure, and East Coast Jewish culture; otherwise you may just feel a slight sense of social exclusion. On the other hand, perhaps unintentionally, the book offers an insight into a world whose public outings are usually more carefully groomed and polished in the interests of impression management.

And of course, this being Nature, all of the above statements are true. Or are they?

Steve Blinkhorn is at Psychometric Research and Development, Brewmaster House, The Maltings, St Albans, Herts AL1 3HT, UK.

\section{Studying form}

Jacob's Ladder: The History of the Human Genome

by Henry Gee

Fourth Estate: 2004. 272 pp. $£ 20$

To be published by Norton in the US in July

\section{Andrew Berry}

Jacob's Ladder opens with an account of human embryonic development. It's a wonderful piece of writing, its lyricism inspired perhaps by Henry Gee's choice of his own daughter as the focal fetus. And it nicely sets up the book's theme: the "question of what it is that produces form from the formless". What follows is an engaging mix of history of science, evolutionary biology and molecular genetics. Much of it is familiar: we see Mendel pottering in the monastery garden, Darwin being seasick on the Beagle, and Hox gene products binding to DNA regulatory regions. But Gee, a senior editor at Nature, has stitched the material together in interesting ways and has plenty of points of his own to make.

One of Gee's messages is that, although "the story of biology can be told in an unbroken skein", the discipline's intellectual history is wilfully ignored. Too often the publication of Darwin's The Origin of Species in 1859 is deemed the starting point of modern biology, to the extent that "if we hear anything at all of biology before Darwin, it is brought up only to be belittled." Gee, then, is on a mission to restore the reputations of the pre-darwinians, and the first part of the book duly pushes a 'nothing new under the sun' thesis.

Take preformationism, the doctrine that

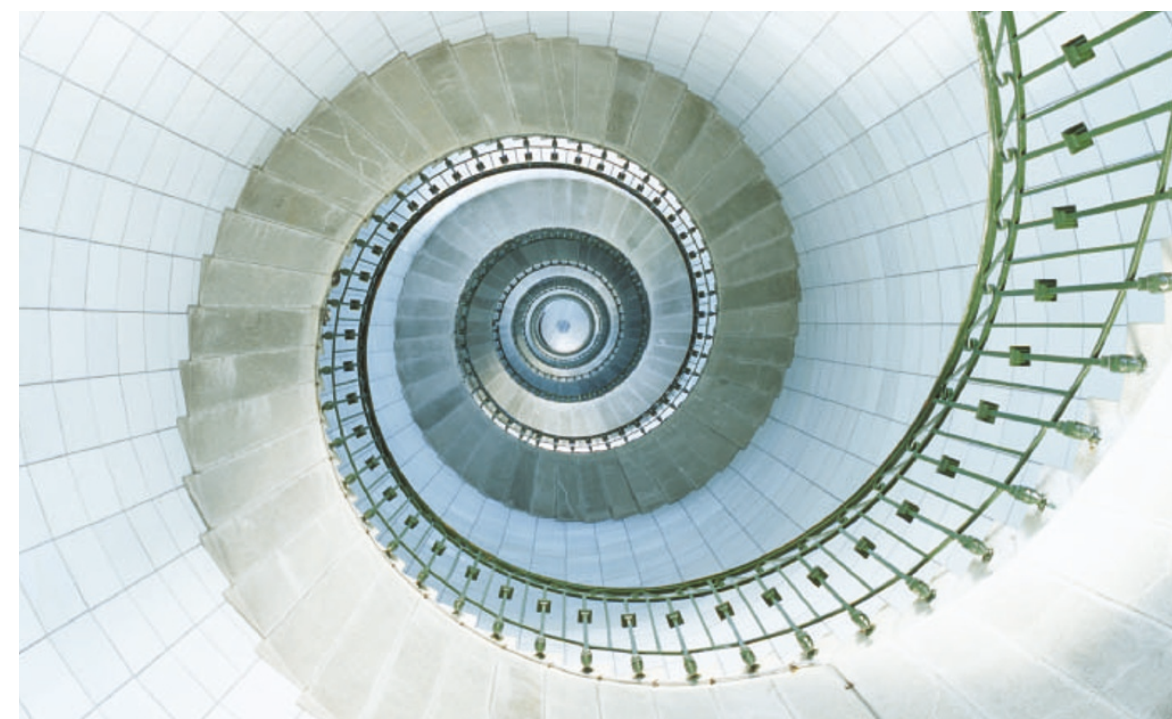

Unravelling the spiral: after sequencing the human genome, how will we attempt to manipulate it?

gametes contain preformed miniature humans (homunculi) and that development is simply a matter of amplifying what is already there. It all seems wonderfully silly to us, especially as the logical corollary is that Eve's ovaries contained, ready formed, the germ of every human to come. But Gee believes that modern biology's proudest achievement, the Human Genome Project, owes much to preformationism. After all, under both preformationism and modern notions of development, "conception does not start life from scratch, but simply activates a program that was already in existence" - that's the genome if you're in the twenty-first century, or the preformed germ if you're in the eighteenth.

Gee is keen that we recognize our debt to our intellectual antecedents, but his purpose is not to induce a spasm of ancestor worship; rather, he sees history as rich in lessons. The genome project was peddled as latterday preformationism - know the sequence, or homunculus, and all of humanity's secrets will be revealed - but the shortcomings of such a conveniently one-dimensional perspective are today amply apparent as pages of journals become clogged with talk of transcriptomes and proteomes, and nobody, to my knowledge, has yet fingered the consciousness gene.

That humanity's secrets have proved less accessible than the hype suggested, Gee believes, could have been predicted by paying proper attention to previous scientific controversies. His respect for the past is laudable, but I need more convincing that intellectual history should be a necessary part of a scientist's education. The example given here is more a condemnation of the rhetoric associated with the genome project than of the scientific work itself. The press and science writers certainly oversold the project, and many scientists participated in the hype. But this wasn't science, it was PR. For such an expensive and high-profile undertaking, PR, like it or not, is a necessary evil.

Jacob's Ladder does not confine itself to the past; indeed the ladder of the title, which in the original in Genesis was populated by angels en route to heaven, symbolizes for Gee a future in which we manipulate our own genome. Whether the resulting ladder will ultimately lead up or down is surely the question, but Gee does not dwell on this. His vision for the future is more short term and more securely scientific: his strongest message is his endorsement of a network approach to biology.

The key to understanding how living systems work lies in uncovering patterns of interaction among genes and their products. Gee is an enthusiastic proponent of what these days is billed as 'systems biology': a combination of high-tech data gathering, computer simulation and big-picture thinking. The ability to study many genes at once and the availability of computers that can perform once-inconceivable combinatorial feats do indeed together represent an exciting opportunity. But, to return to Gee's "unbroken skein" of the history of biology, I don't see it as a major departure from what has gone before.

Population geneticists - a species that seems to try Gee's patience - have long grappled with multilocus problems. With biochemists, they have long studied the properties of a particular kind of network, the biochemical pathway. Even the currently fashionable developmental networks were extensively treated by population geneticists such as C. H. Waddington more than 50 years ago. Gee is absolutely correct to point to network analysis as a major way forwards. But it is ironic, in view of his embrace of biology's past, that he does so with a lack of regard for what came before.

Andrew Berry is at the MCZ Labs, Harvard

University, Cambridge, Massachusetts 02138, USA. 